\title{
Motivations for inadequate persistence with disease modifying anti-rheumatic drugs in early rheumatoid arthritis: the patient's perspective
}

\author{
Virginia Pascual-Ramos ${ }^{*}$ and Irazú Contreras-Yáñez
}

\begin{abstract}
Background: Knowledge of factors that contribute to non-persistence with disease modifying anti-rheumatic drugs (NP) is essential to improve rheumatoid arthritis (RA) outcomes. Aims of the study were to investigate patient's motivations and risk factors for NP in a cohort of early RA patients.

Methods: Up to September 2012, data from 149 patients, who had at least 1 year of follow-up, at least one drug indication, and at least 2 consecutive six-months-apart rheumatic evaluations that included assessment of compliance were reviewed. NP and patient's motivations of NP were evaluated according to a questionnaire. NP was defined when patients referred that they had completely stop RA medication, "Sometimes", "Almost always" or "Always". Patients had to pay for their medication.

Descriptive statistics and logistic regression models were used. Statistical significance was set at a p value of less than 0.05 . The study was approved by the internal review board.

Results: Up to cut-off, 715 questionnaires were applied to 149 patients, who had follow-up of $58.7 \pm 27.9$ months and were indicated $2.4 \pm 0.7 \mathrm{DMARDs} /$ patient/follow-up.

Patients were most frequently female (88.6\%), middle-aged ([mean $\pm \mathrm{SD}]$ age of $38.5 \pm 12.8$ years) with lowermiddle/lower socio-economic status (87.9\%) and scholarship of $11 \pm 3.9$ years.

Ninety-nine (66.4\%) patients were NP and filled 330 questionnaires. Multivariate analysis showed that years of formal education (OR: 1.12, 95\% Cl: 1.1-1.24, $\mathrm{p}=0.03$ ), perception of at least some difficulty to find arthritis medication (OR: $5.68,95 \% \mathrm{Cl}: 2.48-13, \mathrm{p}=0.000)$ and perception that arthritis medication is expensive (OR: 5.27 , $95 \% \mathrm{Cl}: 2.1-13.84, \mathrm{p}=0.001)$ at the first evaluation of patient's compliance were all predictors of NP.

Among the 99 NP patients, 25 (25.3\%) were recurrent-NP and accumulated more disease activity. The combination of both reasons of NP ("Because it was not available at the drugstore" and "Because the medication is very expensive") when selected at the first evaluation of compliance was the only variable to predict recurrent NP, OR: 4.8, 95\% Cl: $1.1-20.8, p=0.04$.
\end{abstract}

Conclusions: Health systems should provide (first line) treatment for RA as a strategy to improve compliance with therapy and clinical outcomes, particularly in vulnerable populations.

\footnotetext{
* Correspondence: virtichu@gmail.com

Department of Immunology and Rheumatology, Instituto Nacional de

Ciencias Médicas y Nutrición Salvador Zubirán, Vasco de Quiroga 15, colonia sección XVI, Tlalpan, México DF 14000, México
} 


\section{Background}

Rheumatoid arthritis (RA) is a chronic inflammatory disease that may result in significant disability, morbidity and increased mortality [1-3]. Patients from LatinAmerica present unique and distinctive epidemiological, serological and clinical features regarding their disease. Published literature highlights a lower prevalence [4], a younger age at presentation $[4,5]$ and a less severe clinical expression [5] when compared to Caucasians.

Current RA treatment guidelines recommend early aggressive management with disease modifying antirheumatic drugs (DMARDs) in order to improve patient's outcomes. However, poor compliance with therapy is a substantial problem that affects $20 \%$ to $70 \%$ of the patients during follow-up [5-16]. Local experience with a cohort of Mexican Mestizo patients with early disease have confirmed these data and additionally shown that poor compliance with traditional DMARDs was associated with increased disease's flares, decreased rates of remission and worse patient-reported outcomes $[5,17,18]$. The impact of inadequate therapy behavior in (early) RA patient's outcomes may be further amplified by the fact that almost all the patients who had poor compliance with drugs eventually dropped out of treatment completely [19]. Furthermore, as a result of undetected or unreported therapeutic non-compliance, physicians may recommend a more complex regimen, which may increase costs and adverse events risks.

Many factors have been related to poor compliance with drugs in patients with RA [20] and include younger age $[9,14]$, male sex $[13,14]$, belonging to ethnic minority [19], lower education [10], side effects [10], availability of financial resources and social support [11], medication taking behavior and beliefs [12], increased disability [13], better perceived health status at the beginning [6], poor quality of contact with health professionals [13], poor personal knowledge about the disease and its treatment [13] and class of DMARDs [8,15]. Published data are obtained from studies performed in developed countries and in populations predominantly Caucasians.

In 2004, we establish an Early Arthritis Clinic in a referral Centre for Rheumatic Diseases in México City. Since the beginning, patient's medication behavior has been assessed, initially through a structured interview and since November 2008 through an instrument locally designed, the Compliance Questionnaire (CQ), that evaluates both constructs, adherence with and persistence (P) on therapy and investigates patient's motivations of inadequate persistence with therapy [16].

In addition to the distinctive features above mentioned, RA patients from Latin-America are frequently uninsured, had a low socio-economical status and are less educated than RA patients from developed countries that may additionally impact compliance and outcomes.
From the perspective of achieving desirable clinical outcomes, the negative effect of poor compliance with DMARDs needs to be minimized. However, in order to formulate effective strategies to contain the problem there is a need to investigate the factors that contribute to poor compliance. The aims of the study were:

1. To investigate most frequent patient's motivations for non-persistence with disease modifying antirheumatic drugs (NP) in early RA Mexican Mestizo patients.

2. To identify risk factors of both, NP and recurrent NP.

\section{Methods}

\section{Setting and study population}

The early arthritis Clinic at the Instituto Nacional de Ciencias Médicas y Nutrición was initiated in 2004. Patients entering the Clinic had disease duration of less than a year when first evaluated and no specific rheumatic diagnosis but with RA. Patients are evaluated every two months during the first 2 years of follow-up and thereafter every 2, 4 or 6 (fixed for all the patients from the baseline evaluation) months depending on patients and disease characteristics. Treatment is prescribed by the rheumatologist in charge of the Clinic and is "treat to target" oriented.

Our Center belongs to the National Institutes of Health from México. Patients had health expenditures government coverage depending on their incomes; coverage varies from 0 to $100 \%$. Most of the patients (70\%) had $70 \%$ of their expenditures covered. Costs that are partially covered include: medical consultations, hospitalizations, emergency room and critical care unit, laboratory and all the diagnostic procedures available. Patients need to pay for their medication and these are not provided by the local pharmacy (unless patients are hospitalized and if available).

\section{Rheumatic evaluations}

At study entry a complete medical history and demographic data are recorded along with disease specific autoantibodies. Medical evaluations are standardized and included swollen and tender joint counts, acute reactant-phase determinations, patient- and physicianreported outcomes, comorbidity, and treatment's assessment (name/s, dose/s and schedule/s of all drug/s they were taking since last visit) along with the evaluation of compliance with therapy.

\section{Therapy behavior evaluation}

Since 2008, the CQ is applied at fixed- six month intervals to all the patients. The $C Q$ is a 22 -items questionnaire (Additional file 1) which evaluates both adherence with and persistence on therapy. Briefly, Items 1 and 2 
are related to demography; items 3 and 4 are related to the use of alternative medicine; items 5 and 6 evaluate patient-physician relationship; in item 7 patients qualify the quality of physician's evaluation and central laboratory facilities; item 8 evaluates availability of medication at the drugstores and item 9 evaluates medication cost patient's perception, both of them use Likert scales; in items 12 to 14, patients use a Likert scale to evaluate adherence to DMARD therapy; items 15, 17, 19 and 21 investigate patient's knowledge about the disease; finally, items 16, 18, 20 and 22 determine the level of social support.

In item 10, patients use a Likert scale (0 to 4 ) to determine NP; patients who scored item 10 as $1,2,3$ or 4 are directed to answer item 11 mean while those who score it as 0 are directed to proceed to item 12; item 11 investigates patient's reasons of inadequate medication taking behavior and includes 15 predefined answers (most of them obtained from literature review) and one open answer.

Performance of the CQ has shown high sensitivity and satisfactory specificity to detect persistence on DMARDs [17]. CQ is fulfilled without help by $95 \%$ of the patients.

\section{Definitions}

Disease activity was defined according to cut-offs of the Disease Activity Score, when 28 joints are examined (DAS28), [21,22].

Disability was evaluated according to the HAQ [23].

A patient was considered to be Persistent if in item 10 "In the past 6 months, how often did you completely stop taking your medication? " boxes 0 ("Never") or 1 ("Almost never") were filled.

A patient was considered to be NP if in tem 10 boxes 2 ("Sometimes"), 3 ("Almost always") and 4 ("Always") were filled.

A patient was considered to be recurrent-NP if he/she was defined as NP at every time the CQ was applied.

\section{Ethics}

The study was approved by the internal review board (Comité de Ética en Investigación del Instituto Nacional de Ciencias Médicas y Nutrición Salvador Zubirán). Written informed consent was obtained in order to have patient's charts reviewed and data presented in scientific forums or published.

\section{Statistics}

Student $\mathrm{t}$ test, one-way ANOVA and $\mathrm{X}^{2}$ were used for normally distributed variables and Mann-Whitney $\mathrm{U}$ for non-normally distributed variables.

To identify baseline predictors for NP and recurrentNP, logistic regression models were used. Those variables bivariately showing a significance level of $\mathrm{p} \leq 0.05$ were included into a regression model. Previously, correlation between selected variables was analyzed. The full multivariate model was reduced by stepwise removal of baseline variables with a significance level of $p \leq 0.05$.

Statistical analysis was performed using the SPSS/PC program (v.12.0; Chicago IL). Statistical significance was set at a $\mathrm{p}$ value of less than 0.05 .

From the present report, data from patients with at least 1 year of follow-up, at least one DMARD indication over follow-up, and at least 2 consecutive six-monthsapart evaluations for compliance were reviewed. Up to September 2012, 149 patients met the inclusion criteria, which corresponded to $93 \%$ of the population of the Early Arthritis Clinic.

\section{Results}

\section{Characteristics of the population}

Up to cut-off, $715 \mathrm{CQ}$ were applied to 149 early RA patients who had (mean \pm SD) follow-up of $58.7 \pm$ 27.9 months and were indicated (mean \pm SD) $2.4 \pm 0.7$ number of DMARDs/patient/follow-up. Main characteristics of the patients at cohort inclusion are summarized in Table 1.

\section{Patient's motivations of NP}

Among the 715 CQ applied, 330 (46.2\%) were classified as NP. Table 2 exhibits patient's motivations and their frequencies.

Every evaluation of compliance was performed as part of a complete rheumatic assessment which included disease activity evaluation as per DAS28. Accordingly, patients were classified as in remission (DAS28 $\leq 2.6)$ in 109 out of 330 evaluations and with disease activity in the remaining 221 evaluations. There were subtle differences in patient's motivations of NP between active patients and patients who achieved remission: formers referred most frequently "I was not at home when I had to take my medication" and "nobody reminded me to take my medication" than their counterparts, as shown in Table 2.

\section{Predictors of NP}

Ninety-nine $(66.4 \%)$ patients were classified as NP at some point during their follow-up and filled $330 \mathrm{CQs}$, meanwhile 50 were classified as persistent (33.6\%) and filled 385 CQs. P and NP patients were compared. No differences were found between groups regarding age, percentage of females, residence, occupation, marital status, health coverage and baseline percentage of patients with RF, baseline - disease activity,- comorbidity and treatment, and cumulative-comorbidity and -treatment (data not shown). Nonetheless, NP patients had more years of formal education, longer follow-up, had more antibodies to cyclic citrullinated peptides (ACCP) and 
Table 1 Characteristics of the population at the baseline evaluation

\begin{tabular}{|c|c|}
\hline Variables & $\begin{array}{c}\text { Population } \\
N=149\end{array}$ \\
\hline \multicolumn{2}{|l|}{ Demographic } \\
\hline Females, $\mathrm{N}^{\circ}(\%)$ & $132(88.6 \%)$ \\
\hline Age at baseline, years, mean \pm SD & $38.5 \pm 12.8$ \\
\hline Years of education, mean \pm SD & $11 \pm 3.9$ \\
\hline \multicolumn{2}{|l|}{ Marital status of the patients, $\mathrm{N}^{\circ}$ ( $\%$ of the patients) } \\
\hline Married & $72(48.3)$ \\
\hline Single & $60(40.3)$ \\
\hline Separated/divorced/widow & $17(11.4)$ \\
\hline \multicolumn{2}{|l|}{ Occupation of the patients, $\mathrm{N}^{\circ}(\%)$} \\
\hline Formal occupation & $56(37.6)$ \\
\hline Housewife & $54(36.2)$ \\
\hline Willing to work & $20(13.4)$ \\
\hline Students & $12(8.1)$ \\
\hline Informal occupation & $7(4.7)$ \\
\hline \multicolumn{2}{|l|}{$\%$ of health expenditures with government coverage } \\
\hline$N^{\circ}(\%)$ of patients with $90 \%$ coverage & $3(2)$ \\
\hline $\mathrm{N}^{\circ}(\%)$ of patients with $80 \%$ coverage & $25(16.8)$ \\
\hline $\mathrm{N}^{\circ}(\%)$ of patients with $70 \%$ coverage & $104(69.8)$ \\
\hline$N^{\circ}(\%)$ of patients with $60 \%$ coverage & $17(11.4)$ \\
\hline \multicolumn{2}{|l|}{ Disease specific autoantibodies } \\
\hline$N^{\circ}(\%)$ of patients with Rheumatoid Factor & $117(78.5)$ \\
\hline $\begin{array}{l}\mathrm{N}^{\circ}(\%) \text { of patients with antibodies to cyclic citrullinated } \\
\text { proteins }\end{array}$ & $117(78.5)$ \\
\hline \multicolumn{2}{|l|}{ Disease characteristics, median (range) } \\
\hline Disease duration, months & $5(3.2-6.8)$ \\
\hline Disease Activity Score, 28 joints evaluated & $6(5.1-7.1)$ \\
\hline Health Assessment Questionnaire & $1.5(0.9-2.1)$ \\
\hline № (\%) patients with $\geq 1$ comorbidity & $88(59.1)$ \\
\hline Median (range) of comorbidity/patient & $1(0-1)$ \\
\hline
\end{tabular}

higher cumulative disease activity and disability than their counterparts, Table 3. Also, they selected more frequently responses "Slightly, Moderately, Quite a bit or Extremely" to the question (Number 8) "In the past six months, how much difficulty did you had to find your arthritis medication at the drugstore?" and to the question (Number 9)" In the past 6 months, how much expensive did you consider was you arthritis medication?" (Table 3).

Multivariate analysis showed that years of formal education (OR: 1.12, 95\% CI: 1.1-1.24, $\mathrm{p}=0.03$ ), perception of at least some difficulty to find arthritis medication (OR: 5.68, 95\% CI: 2.48-13, $\mathrm{p}=0.000$ ) and perception that arthritis medication is expensive (OR: $5.27,95 \% \mathrm{CI}$ :
2.1-13.84, $\mathrm{p}=0.001)$ at the first evaluation of patient's therapy behavior were all predictors of NP (age and gender correction was done).

\section{Predictors of recurrent NP}

As it has been demonstrated that persistence impacts outcomes, we ought to define if there was a particular number of times a patient had to be NP in order to have greater disease activity and disability. Recurrent-NP patients had greater disease activity and disability than their counterparts, (mean \pm SD) cumulative DAS28: $3.7 \pm 2$ vs. $2.9 \pm 1.7, \mathrm{p}=0.04$ and cumulative HAQ: $0.3 \pm 0.2$ vs. $0.1 \pm 0.1, \mathrm{p}=0.05$.

Among the 99 NP patients, 25 (25.3\%) were recurrent$\mathrm{NP}$ and their characteristics were compared to their counterparts (74 patients); no differences were found between groups besides those related to disease activity and disability. The number of patients with DAS28 remission was lower among recurrent-NP patients (45 vs. $8, \mathrm{p}=0.002)$ as was the number of patients with disease activity improvement according to European League Against Rheumatism (EULAR) categories (11 vs. 62, $\mathrm{p}=0.000$ ).

Logistic regression models were constructed in order to investigate predictors on recurrent-NP; in all of them, any possible combination of the 15 patient's motivations of NP when referred at first evaluation of compliance were included. Models yield similar results: the combination of both reasons of NP ("Because it was not available at the drugstore" and "Because the medication is very expensive") when mentioned at the first time the $\mathrm{CQ}$ is applied was the only variable to predict recurrent NP, OR: 4.8, 95\%CI: 1.1-20.8, $\mathrm{p}=0.04$. Results were similar after correction for disease duration, gender and age at disease onset.

\section{Discussion}

From the perspective of healthcare providers, therapeutic compliance is a major clinical issue in RA patients as it impacts disease's outcomes $[5,17,18]$. Inadequate medication adherence (which includes three major components: persistence, initiation adherence and execution adherence) causes an increased financial burden for society as it has been associated to excess emergency care visits and hospitalizations, higher treatment costs and loss of productivity. Furthermore, as a result of undetected or unreported therapeutic noncompliance, physicians may change the regimen, which may increase the cost or complexity of the treatment and eventually the incidence of adverse events. One logical target in trying to complete the riddle of therapeutic non-compliance in RA would be to identify most common associated factors from the patient's perspective and to identify predictors as we did in the present 
Table 2 Patient's motivations for non-persistence and comparison of patient's motivations during remission and disease activity states

\begin{tabular}{|c|c|c|c|c|}
\hline & $\begin{array}{c}\mathrm{N}^{\circ}(\%) \text { of times a } \\
\text { motivation is referred } \\
\text { among } 330 \mathrm{CQ}\end{array}$ & $\begin{array}{l}\mathrm{N}^{\circ}(\%) \text { of times a motivation is } \\
\text { referred among } 109 \mathrm{CQ} \text { applied in } \\
\text { remission states }\end{array}$ & $\begin{array}{l}\mathrm{N}^{\circ}(\%) \text { of times a motivation is } \\
\text { referred among } 221 \mathrm{CQ} \text { applied in } \\
\text { active disease }\end{array}$ & $\mathbf{P}$ \\
\hline \multicolumn{5}{|l|}{ Patient's motivations } \\
\hline Because I forget to take it & $143(43.3)$ & $43(39.4)$ & $100(45.2)$ & 0.38 \\
\hline Because I had no money to buy it & $112(33.9)$ & $41(37.6)$ & $71(32.1)$ & 0.39 \\
\hline $\begin{array}{c}\text { Because it was not available at the } \\
\text { drugstore }\end{array}$ & $100(30.3)$ & $32(29.4)$ & $68(30.8)$ & 0.89 \\
\hline Because I did not buy it & $98(29.7)$ & $30(27.5)$ & $68(30.8)$ & 0.63 \\
\hline $\begin{array}{l}\text { Because I was not at home when I } \\
\text { had to take my medication }\end{array}$ & $91(27.6)$ & $22(20.2)$ & $69(31.2)$ & 0.05 \\
\hline $\begin{array}{c}\text { Because the medication is very } \\
\text { expensive }\end{array}$ & 79 (23.9) & $27(24.8)$ & $52(23.5)$ & 0.91 \\
\hline $\begin{array}{l}\text { Because I had to do more things } \\
\text { than I usually do through the day }\end{array}$ & $60(18.2)$ & $14(12.8)$ & $46(20.8)$ & 0.10 \\
\hline Because I went out on a trip & $40(12.2)$ & $9(8.3)$ & $31(14)$ & 0.18 \\
\hline $\begin{array}{l}\text { Because timing/s when my } \\
\text { medication is prescribed is } \\
\text { different from mealtime/s }\end{array}$ & $30(9.1)$ & $11(10.1)$ & $19(8.6)$ & 0.81 \\
\hline $\begin{array}{l}\text { Because I am taking a lot of } \\
\text { medication at this time }\end{array}$ & $25(7.6)$ & $13(11.9)$ & $12(5.4)$ & 0.06 \\
\hline $\begin{array}{c}\text { Because it may me feel worse } \\
\text { when I take it }\end{array}$ & $23(7)$ & $9(8.2)$ & $14(6.3)$ & 0.68 \\
\hline $\begin{array}{c}\text { Because it does not make me feel } \\
\text { better }\end{array}$ & $19(5.8)$ & $9(8.2)$ & $10(4.5)$ & 0.26 \\
\hline $\begin{array}{l}\text { Because nobody reminded me to } \\
\text { take my medication }\end{array}$ & $15(4.6)$ & $1(0.9)$ & $14(6.3)$ & 0.05 \\
\hline $\begin{array}{c}\text { Because nothing happens if I do } \\
\text { not take it }\end{array}$ & $8(2.4)$ & $5(4.6)$ & $13(5.9)$ & 0.82 \\
\hline $\begin{array}{l}\text { Because I did fewer things than I } \\
\text { usually do through the day }\end{array}$ & $5(1.5)$ & $2(1.8)$ & $3(1.4)$ & 0.88 \\
\hline
\end{tabular}

study developed in a well characterized population of Mexican Mestizo early RA patients.

We found that 2 out of 3 patients were classified as NP. In the literature, different studies have targeted adherence to DMARDs $[5,6,9,10,13,15,16,24]$ and shown that the extent to which patients adhere to DMARD therapy varies between underuse and overuse. Such variations may be explained by differences in sample's size, methods capturing medication adherence, variable disease duration, follow-up, disease activity and therapeutic modalities, although studies confirm that adherence in RA is suboptimal. An important point to consider is that medication adherence is a dynamic feature, not stable over time. We found that $25 \%$ of our patients were consistently NP similar to have been reported in longitudinal studies performed in other RA populations $[5,14,25]$.

Factors identified from studies and reviews with poor compliance may be grouped into several categories, and divided into 5 domains according to the World Health
Organization: namely patient-centered factors, therapyrelated factors, healthcare systems factors, social and economic factors, and disease factors [20,26]. In our study, NP patients were directed to select at least one factor from a list; factors were included in the list as all of them have been shown to impact compliance in different populations $[17,20,26]$. Most frequent patient's motivations for NP were forgetfulness, lack of financial resources and lack of availability at the drug store. Forgetfulness is a widely reported factor that causes non-compliance with both, medication and clinical appointments in different populations, including Mexican patients with type2-diabetes [27,28]. Meal frequency has been shown to be an effective tool to remind the patient to take his medications in Japanese patients [29] and this strategy could be intensified in order to improve compliance. Interestingly, in our study "forgetfulness" was highly correlated to the motivation "Because timing/s when my medication is prescribed is different from mealtime/s "(Rho: 0.92, $\mathrm{p}=0.001$, data not shown). Also, written 
Table 3 Differences between non-persistent (NP) and persistent patients

\begin{tabular}{|c|c|c|c|}
\hline & $\begin{array}{l}\text { NP patients } \\
\qquad N=99\end{array}$ & $\begin{array}{l}\text { Persistent patients } \\
\qquad \mathrm{N}=50\end{array}$ & $\mathrm{p}$ \\
\hline (Mean \pm SD) years of formal education & $11.4 \pm 3.8$ & $10 \pm 3.9$ & 0.03 \\
\hline (Mean \pm SD) months of follow-up & $62.7 \pm 26.4$ & $50.1 \pm 29.5$ & 0.009 \\
\hline $\mathrm{N}^{\circ}(\%)$ of patients with $\mathrm{ACCP}$ when entering the Clinic & $83(84)$ & $34(68)$ & 0.04 \\
\hline (Mean \pm SD) cumulative DAS28 & $3.1 \pm 1.8$ & $2.2 \pm 1.1$ & 0.001 \\
\hline (Mean \pm SD) cumulative $\mathrm{HAQ}$ & $0.4 \pm 0.4$ & $0.3 \pm 0.3$ & 0.03 \\
\hline $\begin{array}{l}\mathrm{N}^{\circ}(\%) \text { of patients who selected responses "Slightly, Moderately, } \\
\text { Quite a bit or Extremely" to the question (Number 8), }\end{array}$ & $57(57)$ & $20(39.5)$ & 0.000 \\
\hline \multicolumn{4}{|l|}{$\begin{array}{l}\text { "In the past six months, how much difficulty did you had to } \\
\text { find your arthritis medication at the drugstore?" }\end{array}$} \\
\hline $\begin{array}{l}\mathrm{N}^{\circ}(\%) \text { of patients who selected responses "Slightly, Moderately, } \\
\text { Quite a bit or Extremely" to the question (Number 9), }\end{array}$ & $92(93)$ & $42(80)$ & 0.002 \\
\hline \multicolumn{4}{|l|}{$\begin{array}{l}\text { In the past } 6 \text { months, how much expensive did you consider } \\
\text { was you arthritis medication }\end{array}$} \\
\hline
\end{tabular}

instructions are better than oral advice for reminding patients to take their medications and we recommend it implementation for every patient, and at every appointment.

Patient's perception of at least "some difficulty to find arthritis medication" (previously reported as lack of availability at the drug store) and that "arthritis medication is expensive" (lack of financial resources) were among the most frequent motivations for NP; when both of them were selected at the first evaluation of patient's compliance, they predicted NP (in addition to a higher education level) and also recurrent- NP. Cost is a crucial issue in patient's compliance especially for patients with chronic diseases $[28,30]$. A number of studies have shown that patients who had no insurance cover or who had low incomes (as our population of patients who had to pay for their medication) are more likely to be noncompliant when compared to patients with health insurance or relatively high incomes [27,31-34]. In RA patients, inadequate or nonexistent reimbursement by health insurance plans has shown to negatively affect adherence to biologics [16]. Also, among the identified health care systems factors that contribute to poor compliance are lack of availability and accessibility to healthcare [28]; a significant percentage of our patients selected lack of availability of the medication which is related to the former. Finally, regarding education level, intuitively it may be expected that patients with higher educational level should have better knowledge about the disease and therapy benefits and accordingly better compliance. García-González et al. [10] found an association between lower education and lower adherence in 102 ethnically diverse patients from Texas, among whom 72 had RA. However, similar to our findings other researchers have shown that non-RA patients with lower educations levels have better compliance $[35,36]$. One possible explanation may be that patients with lower education level might have more trust in physician's advice. DiMatteo proposed that even highly educated patients may not understand their conditions and the benefits of being compliant [37].

In our study, most frequent patient's motivations for NP were "unintentional" motivations. As opposed to intentional motivations, they reflect a person's ability and skill at medicine taking, including forgetting, poor manual dexterity, losing medicines or not being able to afford them. Meanwhile, intentional non-adherence is a behavior driven by the decision not to take medicines [11,25,38]; drivers of this decision have been suggested to be based on patient's beliefs about its illness and its treatment, which can be further categorized as perceived benefits and perceived concerns [25]. Neame et al. reported that most people with RA had positive beliefs regarding the necessity of their medication but levels of concern were also high and were positively associated to poor compliance as $91 \%$ of non-adherent RA patients had at least one concern about potential adverse events [39]. Besides the valuable conceptual distinction between intentional and non-intentional motivations of nonadherence in RA patients, a practical approach to poor patient's medication behavior will be to identify individual main drivers of poor compliance and tailor the content of the adherence-improving-intervention to the individual patient's motivation of non-adherence [40]. This comprehensive strategy may be more effective that 
traditional adherence intervention programs in RA that have shown inconsistent and limited effects [41-43]; furthermore, it can be applied in our population as $79 \%$ of our patients selected non-intentional motivations and among them, $66 \%$ selected exclusively non-intentional motivations during their follow-up meanwhile $28 \%$ selected both, intentional and non-intentional motivations (data not shown). This finding is in agreement with the fact that there were no major differences between active and inactive patients with NP.

Some limitations of the study need to be addressed. We did not use a well-validated questionnaire scale to assess persistence; we applied a short-patient-oriented questionnaire, locally designed which has shown adequate internal consistency, high sensitivity and satisfactory specificity to detect persistence on DMARDs [17]. We did analyze neither the construct of adherence nor major factors associated. This study was done in an inception cohort of early RA patients, with particular socio-demographic characteristics, ethnicity, treatment and health system and our results may not be generalized to RA populations with different characteristics [4].

Compliance with medication is a dynamic process and fluctuates over time; with a more extended length of follow-up, patients formerly classified as persistent with therapy may become non-persistent. We limited the study of factors associated to medication persistence, to patient's motivations; ultimately, it is the patient who decides whether or not to take his/her medication as prescribed, and non adherent patient's opinion are essential in order to design effective interventions. Finally, we investigate a limited number of patient's motivations for non-persistence with medication although they were selected based on the existing literature.

\section{Conclusions}

Almost half of Mexican Mestizo patients with early RA and partial health coverage do not take their disease modifying anti-rheumatic drugs as directed. Most frequent patient's motivations for non persistence were non-intentional motivations as forgetfulness, lack of financial resources and lack of availability at the drug store. When patients identified concomitantly "some difficulty to find arthritis medication and that arthritis medication is expensive" at their first evaluation of compliance with therapy they may be at risk of nonpersistence during their follow-up and of deleterious outcomes. Health systems should provide (first line) treatment for RA as a strategy to improve compliance with therapy and clinical outcomes.

\section{Additional file}

Additional file 1: Compliance Questionnaire.

\section{Abbreviations}

RA: Rheumatoid arthritis; DMARDs: Disease modifying drugs; $C Q$ : Compliance questionnaire; P: Persistence; NP: Non-persistence with disease modifying anti-rheumatic drugs; DAS28: Disease Activity Score (28 joints evaluated); HAQ: Health assessment questionnaire; ACCP: Antibodies to cyclic citrullinated peptides.

\section{Competing interests}

The authors declare that they have no competing interests.

\section{Authors' contributions}

VPR participated in the design and conception of the study, performed clinical evaluations and acquired data, drove statistical analysis and drafted the manuscript. ICY participated in the study design and conception, performed statistical analysis and helped to draft the manuscript.

Both authors read and approved the final manuscript.

Received: 4 July 2013 Accepted: 26 November 2013

Published: 1 December 2013

\section{References}

1. Kosinski M, Kujawski SC, Martin R, Wanke LA, Buatti MC, Ware JE Jr, Perfetto EM: Health-related quality of life in early rheumatoid arthritis: impact of disease and treatment response. Am J Manag Care 2002, 8:231-40.

2. Sanderson T, Kirwan J: Patient-reported outcomes for arthritis: time to focus on personal life impact measures? Arthritis Rheum 2009, 61:1-3.

3. Wolfe F, Mitchell DM, Sibley JT, Fries JF, Bloch DA, Williams CA, Spitz PW, Haga M, Kleinheksel SM, Cathey MA: The mortality of rheumatoid arthritis. Arthritis Rheum 1994, 37:481-494.

4. Mody GM, Cardiel MH: Challenges in the management of rheumatoid arthritis in developing countries. Best Pract Res Clin Rheumatol 2008, 22:621-641.

5. Pascual-Ramos V, Contreras-Yáñez I, Villa AR, Cabiedes J, Rull-Gabayet M: Medication persistence over 2 years of follow-up in a cohort of early rheumatoid arthritis patients: associated factors and relationship with disease activity and with disability. Arthritis Res Ther 2009, 11:R26. doi:10.1186/ar2620.

6. de Klerk E, van der Heijde D, Landewé R, van der Tempel H, Urquhart J, van der Linden S: Patient Compliance in rheumatoid arthritis, polymyalgia rheumatica, and gout. J Rheumatol 2003, 30:44-54.

7. Gossec L, Tubach F, Dougados M, Ravaud P: Reporting of adherence to medication in recent randomized controlled trials of 6 chronic diseases: a systematic literature review. Am J Med Sci 2007, 334:248-254.

8. Deyo RA, Inui TS, Sullivan B: Noncompliance with arthritis drugs: magnitude, correlates, and clinical implications. J Rheumato/ 1981, 8:931-936.

9. Tuncay R, Eksioglu E, Cakir B, Gurcay E, Cakci A: Factors affecting drug treatment compliance in patients with rheumatoid arthritis. Rheumatol Int 2007, 27:743-746.

10. García-González A, Richardson M, García Popa-Lisseanu M, Cox V, Kallen MA, Janssen N, Ng B, Marcus DM, Reveille JD, Suárez-Almazor ME: Treatment adherence in patients with rheumatoid arthritis and systemic lupus erythematosus. Clin Rheumatol 2008, 27:883-889.

11. Lorish CD, Richards B, Brown S: Missed medication doses in rheumatic arthritis patients: intentional and unintentional reasons. Arthritis Care Res 1989, 2:3-9.

12. Lorish $C D$, Richards $B$, Brown $S$ Jr: Perspective of the patient with rheumatoid arthritis on issues related to missed medication. Arthritis Care Res 1990, 3:78-84.

13. Viller F, Guillemin F, Briançon S, Moum T, Suurmeijer T, van den Heuvel W: Compliance to drug treatment of patients with rheumatoid arthritis: a 3 year longitudinal study. J Rheumatol 1999, 26:2114-2122.

14. Viller F, Guillemin F, Briançon S, Moum T, Suurmeijer T, van den Heuvel W: Compliance with drug therapy in rheumatoid arthritis. A longitudinal European study. Joint Bone Spine 2000, 67:178-182.

15. Grijalva CG, Chung CP, Arbogast PG, Stein CM, Mitchel EF Jr, Griffin MR: Assessment of adherence to and persistence on disease-modifying 
anti-rheumatic drugs (DMARDs) in patients with rheumatoid arthritis. Med Care 2007, 45(Suppl 2):S66-76.

16. Curkendall S, Patel V, Gleeson M, Campbell RS, Zagari M, Dubois R: Compliance with biologic therapies for rheumatoid arthritis: do patients out-of-pocket payments matter? Arthritis Rheum 2008, 59:1519-1526.

17. Contreras Yanez I, Ponce De Leon S, Cabiedes J, Rull Gabayet M, Pascual Ramos V: Inadequate therapy behavior is associated to disease flares in patients with rheumatoid arthritis who have achieved remission with disease modifying anti-rheumatic drugs. Am J Med Sci 2010, 340:282-290.

18. Contreras-Yáñez I, Cabiedes J, Villa AR, Rull-Gabayet M, Pascual-Ramos V: Persistence on therapy is a major determinant of patient-, physician-, and laboratory reported outcomes in recent-onset rheumatoid arthritis patients. Clin Exp Rheumatol 2010, 28:748-51.

19. Lim TO, Ngah BA: The Mentakab hypertension study project. Part IIwhy do hypertensives drop out of treatment? Singapore Med J 1991 32:249-251.

20. Jin J, Sklar GE, Min Sen Oh V, Chuen Li S: Factors affecting therapeutic compliance: a review from the patient's perspective. Ther Clin Risk Manag 2008, 4:269-286.

21. Prevoo ML, Van T, Hof MA, Kuper HH, Van Leeuwen MA, Van De Putte LB, Van Riel PL: Modified disease activity scores that include twenty-eightjoint counts. Development and validation in a prospective longitudinal study of patients with rheumatoid arthritis. Arthritis Rheum 1995, 38:44-48.

22. Aletaha D, Ward MM, Machold KP, Nell VP, Stamm T, Smolen JS: Remission and active disease in rheumatoid arthritis: defining criteria for disease activity states. Arthritis Rheum 2005, 52:2625-2636.

23. Ramey DR, Raynauld JP, Fries JF: The health assessment questionnaire 1992; status and review. Arthritis Care Res 1992, 5:119-129.

24. Lee $P$, Tan $\sqcup$ : Drug compliance in outpatients with rheumatoid arthritis. Aust N Z J Med 1979, 9:274-277.

25. van den Bemt BJ, Zwikker HE, van den Ende $\mathrm{CH}$ : Medication adherence in patients with rheumatoid arthritis: a critical appaisal of the existing literature. Expert Rev Clin Immunol 2012, 8:337-351.

26. World Health Organization: Adherence to long-term therapies: evidence for action. 2003 [www.who.int/chp/knowledge/publications/adherence full_report.pdf].

27. Hernández-Ronquillo L, Téllez-Zenteno JF, Garduño-Espinosa J, GonzálezAcevez E: Factors associated with therapy non-compliance in type 2-diabetes patients. Salud Publica Mex 2003, 45:191-197.

28. Ponnusankar S, Surulivelrajan M, Anandamoorthy N, Suresh B: Assessment of impact of medication counseling in patient's medication knowledge and compliance in an outpatient clinic in South India. Patient Educ Couns 2004, 54:55-60.

29. Okuno J, Yanagi H, Tomura S, Oka M, Hara S, Hirano C, Tsuchiya S: Compliance and medication knowledge among elderly Japanese home-care recipients. Eur J Clin Pharmacol 1999, 55:145-149.

30. Ellis JJ, Erickson SR, Stevenson JG, Bernstein SJ, Stiles RA, Fendrick AM: Suboptimal statin adherence and discontinuation in primary and secondary prevention populations. J Gen Intern Med 2004, 19:638-645.

31. Kaplan RC, Bhalodkar NC, Brown EJ Jr, White J, Brown DL: Race, ethnicity and sociocultural characteristics predict noncompliance with lipidlowering medications. Prev Med 2004, 39:1249-1255.

32. Swett C Jr, Noones J: Factors associated with premature termination from outpatient treatment. Hosp Community Psychiatry 1989, 40:947-951.

33. Mishra P, Hansen EH, Sabroe S, Kafle KK: Socio-economic status and adherence to tuberculosis treatment: a case control study in a district of Nepal. Int J Tuberc Lung Dis 2005, 9:1134-1139.

34. Ghods AJ, Nasrollahzadeh D: Noncompliance with immunosuppressive medications after renal transplantation. Exp Clin Transplant 2003, 1:39-47.

35. Kyngas $\mathrm{H}$, Lahdenpera $\mathrm{T}$ : Compliance of patients with hypertention and associated factors. J Ad Nur 2000, 29:832-839.

36. Senior V, Marteau TM, Weinman J: Self-reported adherence to cholesterollowering medication in patients with familial hypercholesterolaemia: the role of illness perceptions. Cardiovas Drug Ther 2004, 18:475-481.

37. DiMatteo MR: Patients adherence to pharmacotherapy: the importance of effective communication. Formulary 1995, 30:596-598. 601-2, 605 .

38. Clifford S, Barber N, Horne R: Understanding different beliefs held by adherers, unintentional nonadherers and intentional nonadherers: application of the necessity-concerns framework. J Psychosom Res 2008, 64:41-46.
39. Neame R, Hammond A: Beliefs about medications: a questionnaire survey of people with rheumatoid arthritis. Rheumatol (oxford) 2005, 44:762-7.

40. van Dulmen S, Sluijs E, van Dijk L, de Ridder D, Heerdink R, Bensing J: Patient adherence to medical treatment: a review of reviews. BMC Health Serv Res 2007, 7:55.

41. Hill J, Bird H, Johnson S: Effect of patient education on adherence to drug treatment for rheumatoid arthritis: a randomised controlled trial. Ann Rheum Dis 2001, 60:869-875.

42. Brus HLM, van de Laar MAFJ, Taal E, Rasker JJ, Wiegman O: Effects of patient education on compliance with basic treatment regimens and health in recent onset active rheumatoid arthritis. Ann Rheum Dis 1998, 57:146-151.

43. van den Bemt BJ, den Broeder AA, van den Hoogen FH, Benraad B, Hekster $Y A$, van Riel PL, van Lankveld W: Making the rheumatologist aware of patients' non-adherence does not improve medication adherence in patients with rheumatoid arthritis. Scan J Rheumatol 2011, 40:192-196.

doi:10.1186/1471-2474-14-336

Cite this article as: Pascual-Ramos and Contreras-Yáñez: Motivations for inadequate persistence with disease modifying anti-rheumatic drugs in early rheumatoid arthritis: the patient's perspective. BMC Musculoskeletal Disorders 2013 14:336.

\section{Submit your next manuscript to BioMed Central and take full advantage of:}

- Convenient online submission

- Thorough peer review

- No space constraints or color figure charges

- Immediate publication on acceptance

- Inclusion in PubMed, CAS, Scopus and Google Scholar

- Research which is freely available for redistribution 